This is an electronic reprint of the original article. This reprint may differ from the original in pagination and typographic detail.

Author(s): Vuorinen, Maarit; Vos, Marita

Title: Challenges in joint place branding in rural regions

Year: $\quad 2013$

Version:

Please cite the original version:

Vuorinen, M., \& Vos, M. (2013). Challenges in joint place branding in rural regions. Place Branding and Public Diplomacy, 9(3), 154-163.

https://doi.org/10.1057/pb.2013.18

All material supplied via JYX is protected by copyright and other intellectual property rights, and duplication or sale of all or part of any of the repository collections is not permitted, except that material may be duplicated by you for your research use or educational purposes in electronic or print form. You must obtain permission for any other use. Electronic or print copies may not be offered, whether for sale or otherwise to anyone who is not an authorised user. 


\title{
Challenges in joint place branding in rural regions
}

\author{
Maarit Vuorinen and Marita Vos \\ University of Jyväskylä, Finland
}

\section{ABSTRACT}

The purpose of this paper is to explore joint place branding in rural regions, focusing on cooperation between the various stakeholders involved and on the salient features of rural regions that are used in the place branding process. Branding is conceptualized as a social process where brand value is cocreated by the stakeholders. Place branding is seen as a participative process, bringing stakeholders together with the aim to strengthen the identity of the place. The fundamental question is how to build long-term commitment in a group of key stakeholders. Many sources discuss place branding for large cities, but rural regions have received little attention. The process of place branding was investigated for three rural regions in Finland. The cooperation in the network of actors was addressed through focus group interviews. Place branding in rural regions is a process needing the combined effort of various stakeholders. Although public organizations are needed to create the preconditions for a joint approach, the efforts of private operators engaged in mutually beneficial relationships are at the heart of successful place branding. The findings show that the establishment of a body to coordinate actions is essential for any place branding effort. It is also suggested that the meaning of landscape is especially important for place branding in rural regions.

Key words: place branding, stakeholder engagement, rural place branding.

\section{BACKGROUND}

The purpose of this paper is to explore joint place branding in rural areas. The focus is on cooperation among the various stakeholders involved and salient features of rural regions used in the place branding process. Brands as constructs are characterized by intangibility and entail multiple dimensions including the perceptions of both organizations and consumers (de Chernatony and Dall'Olmo Riley, 1998). By conceptualizing places as brands, not only can competitive advantage be achieved, but also community development, thereby reinforcing local identity and the identification of citizens with their place of residence, and activating all local social forces (Kavaratzis, 2004). Thus place branding is also about social and economic policies. Places must engage with the outside world in a clear, coordinated and communicated way, if they are to influence public opinion (Anholt, 2008). Consequently, a place branding strategy can support the aims of stakeholders in helping to increase the attractiveness of a place on the basis of its authentic features (Hospers, 2004).

In this paper, we focus on the joint effort of actors from the public and private sector to develop the features of rural regions. Below we clarify what the literature on place branding reveals about the process of joint place branding and the cooperation it requires. Although studies on place branding have devoted little attention to rural regions, mention will be made of insights found in the literature that relate to the specifics of their place branding. We then report our study on how place branding in three rural regions in Finland has been approached. 


\section{Place branding as a cooperative process}

A place is characterized by an open system of interdependent, multiple stakeholders, where the actions of one stakeholder impact on the other actors in the community (Jamal and Getz, 1995). Place branding needs to bring together and negotiate the interests of the various interdependent social actors (Lichrou et al., 2010). The brand core may be the vision of one or more organizations, and it may change as the brand develops and is repositioned (Hankinson, 2004). Branding is a form of communicative interaction and works by integrating and getting stakeholders together (Ballantyne and Aitken, 2007). Brand conceptualization has thus shifted from brands as identifiers to brands as social processes, where brand value is co-created by the stakeholders (Szondi, 2010). In place branding stakeholder participation forms the place branding process itself (Kavaratzis, 2012), getting people together to address shared identity of the place. This shift to co-creation is in line with the evolving service-dominant paradigm of marketing proposed by Vargo and Lusch (2004), who consider service the common denominator of exchange processes. Services form the core of the place product and provide the benefits that the place brand offers. These services are delivered in a physical environment comprising buildings and other features of the environmental landscape. Similarly, the place brand has diverse ownership, and hence its management is a collaborative undertaking of the place's key stakeholders (Baker and Cameron, 2008). In this study, brand conceptualisation is based on the relational paradigm of exchange with value creation through relationships with stakeholders.

Szondi (2010) proposes relationship building as the central concept and ultimate goal of place branding. The success of a place branding strategy relies on the effective extension of the core brand through relationships with stakeholders, thereby reinforcing the reality of the core brand through consistent communication and delivery of services. What especially matters are the number and quality of the relationships developed with stakeholders in the region (Papadopoulos and Heslop, 2002). These relationships can be grouped into four macro-categories of stakeholders: primary services providers (i.e. business and industrial sector, local entrepreneurs), infrastructure services providers (i.e. government, area development body), the media and communications players (i.e. communication authorities and marketing agencies), and the clients of the place (visitors and residents).

A place brand by its very nature belongs to the place and its people (Hankinson, 2004), while the identity and feeling of the place and local significance are central factors in competing successfully with other places (Murray, 2001). To launch local activities, the existence of a local identity is needed (Berglund, 1998). For an individual, the central factors in identifying with a place are level of involvement and personal sense of attachment (Knuuttila, 1998). It follows from this that participation in joint activities will have an impact on the identity of the individual. Thus, local identity can be seen to have a central role in the task of developing a place as a brand (Rannikko, 2000).

Place branding initiatives focus on local resources and local development, and are driven by the needs of the stakeholders (Rainisto, 2003). Consequently, obtaining stakeholder consensus is an important step in place branding. Localisation is seen as a keyword here, defined as capitalizing on the cultural, economic, social, and physical resources of a particular place, coupled with local organization and networking (Cawley et al., 2002). The local government is generally responsible for the overall image of a place, but the views of local entrepreneurs and small businesses are also a vital concern, as these organizations are the economic engines of the place (Kavaratzis and Ashworth, 2008). Places with strong voluntary activities are better able to utilize initiatives and local resources (Warner, 2001).

Instead of a managerial exercise in decision making about the future of a place, place branding is seen as a collective exercise in defining the meaning of the place for the various stakeholders (Aitken and Campelo, 2011; Kavaratzis and Hatch, 2013).The relational approach adopted by Hankinson (2004) 
describes place branding, in essence, as a set of relationships with stakeholders that spread the core of the place brand.

Baker (2007) suggests that by adopting a brand-as-dialogue approach different voices of stakeholder groups can contribute to building the place brand. Similarly, Gregory (2007) proposed the concept of a 'negotiated brand', as this is vital to bring the differing desires of the various stakeholders together in creating brand value. While engaging stakeholders with different views is likely to bring disagreement and debate, new perspectives and ideas may also be generated (Houghton and Stevens, 2011). This approach is in line with Aitken and Campelo's (2011) proposition that the place brand engages in a "multilogue" with a variety of stakeholders.

According to Merz and Vargo (2009) brand value is co-created through relationships and social interactions among all stakeholders. There is evidence that the most effective place branding initiatives are those involving a wide range of local stakeholders (Houghton and Stevens, 2011), while initiatives which do not engage, and in some cases alienate, local stakeholders are likely to fail (Houghton and Stevens, 2011). Therefore, there is a need to re-examine which stakeholders are given the right to participate in the place branding process and on what basis such rights are given (Kavaratzis, 2012; Hatch and Schultz, 2010). Szondi (2010) proposes relationship building as the central concept of place branding. The success of a place branding strategy relies on the effective extension of the core brand through relationships with stakeholders, thereby reinforcing the reality of the core brand. Thus, stakeholder participation is a central activity in the place branding process.

\section{Landscape-related experiences as a feature of place branding}

The specificity of a place depends on personal unique experiences and the meanings associated with those experiences (Entrikin, 1991). Such experiences are hard to manage, as everyone is free to choose and 'consume' the products and services related to the place. The success of place branding is usergenerated, and a place will always be good enough for someone for something (Rainisto, 2003; Hildreth, 2010).

Branding can focus on particular features of the place; especially in the case of rural places, this often involves the landscape and related experiences. Landscape is one possible way to experience the environment of a place and invest it with meanings. Landscape is readily available as a medium for communication, and branding the landscape will encourage local groups and initiatives (Maessen et al., 2007). Therefore, this needs to be considered when investigating rural places. High quality can be used as niche attribute connected with local natural, cultural and social resources (Cawley et al., 2010). The natural environment can be experienced as enabling a perfect connection with nature and a source of power for the individual. The natural environment can be a 'thought clearing' experience, as a result of which one's own life can be seen from different perspectives (Lüthje, 2005). For example, the southwest Finland archipelago could induce experiences of these kinds.

When, as a brand, a place is experienced by several senses simultaneously, the overall experience is more powerful (Lindström, 2005; Tarssanen and Kylänen, 2006). Individuals today seem to want more from places than just a view and sights (Franklin, 2003). Traditionally, aesthetic pleasure has been connected with vision and hearing, but other senses can also be part of experiencing a landscape (Berleant, 1997). A landscape can be a primary target of experience; it can remain quietly in the background (Tuan, 1974; Relph, 1986) or it can be interpreted through action (Silvennoinen et al., 1998; Lüthje, 2005), for example, trekking in the wild, skiing down snowy slopes, or picking berries in the woods. Place branding is increasingly about experiences and lifestyles (King, 2002). Place products and services are framed as part of the place experience (Pine and Gilmore, 1999). Place branding in rural 
areas can also be addressed as counter-urbanization, where rural space represents 'quality of life' (Murdoch, 2006). The characteristics and concepts used in the place branding of rural areas differ, but, in all cases, the aim is to create a strong place identity that has economic and social benefits. Through a joint effort, the features of a place can be further developed, while, especially for rural regions, the landscape is an important feature that adds meaning to the place and creates opportunities for related experiences.

\section{THE STUDY}

The place branding of rural areas has received little attention in the literature. The purpose of this study is to explore joint place branding in rural areas with a focus on cooperation among the various stakeholders and the salient features to be used in the place branding process. The research questions were: What is the current status of the stakeholder involvement in the place branding of rural regions (RQ1)? How is cooperation organized among the stakeholders (RQ2)? What features of places are used by the stakeholders in branding the rural region (RQ3)?

The process of place branding and the cooperation between the different stakeholders involved was investigated for three rural regions in Finland. In each region a focus group interview was conducted. This is a way of collecting qualitative data by asking a small number of people to participate in a group session and encouraging discussion between the participants (Barbour, 2008; Morgan, 1988). This method generates rich data across a range of opinions and helps to understand perceptions, group processes and interaction between the participants (Bryman, 2004; Bloor et al., 2001; Barbour, 2008).

The focus groups were carried out in the following regions in Finland: Kainuu, the Finnish LakeDistrict, and the coastal region of Southern Finland. The regions were chosen to exemplify different cases while sharing the following features: (1) small, middle-sized rural or remote region with distinctive natural environment or landscape characteristics, and (2) actively seeking new forms for joint place branding and having some experience of development projects.

In each region 8-10 key actors were brought together (see table 1). The participants represented various organizations actively participating in decision making and planning and implementing operational tasks in place branding. This included, for example, representatives of the local tourist board and related organizations - resorts and companies, sporting bodies, governing bodies, cultural institutes, companies, and promotion agencies.

Table 1. The composition of the focus groups according to the stakeholder categories represented

\begin{tabular}{|l|c|c|c|}
\hline Region & KAINUU & $\begin{array}{c}\text { THE FINNISH } \\
\text { LAKE- } \\
\text { DISTRICT }\end{array}$ & $\begin{array}{c}\text { THE COASTAL } \\
\text { REGION } \\
\text { OF FINLAND }\end{array}$ \\
\hline $\begin{array}{l}\text { Date of the focus } \\
\text { group interview }\end{array}$ & $09-01-2011$ & $09-07-2011$ & $09-13-2011$ \\
\hline $\begin{array}{l}\text { STAKEHOLDER } \\
\text { CATEGORY: }\end{array}$ & & & 2 \\
\hline $\begin{array}{l}\text { Tourism management } \\
\text { and marketing, } \\
\text { boards and governing } \\
\text { bodies }\end{array}$ & 1 & 1 & 2 \\
\hline $\begin{array}{l}\text { Cultural institutes, } \\
\text { companies and } \\
\text { organizations }\end{array}$ & - & 1 & \\
\hline
\end{tabular}




\begin{tabular}{|l|c|c|c|}
\hline $\begin{array}{l}\text { Marketing and } \\
\text { communication } \\
\text { authorities or agencies }\end{array}$ & 2 & 1 & 2 \\
\hline $\begin{array}{l}\text { Business and } \\
\text { industrial sector, local } \\
\text { entrepreneurs }\end{array}$ & 3 & 2 & 2 \\
\hline $\begin{array}{l}\text { Regional development } \\
\text { body, business and } \\
\text { corporation } \\
\text { consulting }\end{array}$ & 1 & 2 & 1 \\
\hline $\begin{array}{l}\text { Landscape } \\
\text { architecture }\end{array}$ & 2 & 1 & - \\
\hline Government & 1 & - & 10 \\
\hline $\begin{array}{l}\text { Total number of } \\
\text { participants }\end{array}$ & 10 & 8 & 1 \\
\hline
\end{tabular}

Each focus group interview lasted about two hours. The themes discussed were: (1) The various stakeholders and their responsibilities in the place branding process; (2) Cooperation among the stakeholders; and (3) Features of the region used in place branding. During the focus group interviews, challenges encountered in the process of joint branding were also addressed.

The focus group interviews were recorded only for the purpose of this study, and after each meeting the tapes were transcribed and anonymized. The transcribed material comprised 81 pages. A thematic analysis was conducted (following e.g. Solatie, 2001), using Atlas computer-assisted qualitative data analysis software. Next, the text passages were coded and sorted according to the three themes drawn from the earlier research. However, the categories and their sub-divisions were evaluated against the empirical data and modified if necessary (following e.g. Flick, 1998). The goal was to reduce the material by producing themed summaries or overviews of the data set to facilitate the reporting of the findings.

\section{THE RESULTS}

Below we report the stakeholder involvement in the network, the network cooperation and the features of place used in the branding of the three rural regions.

\section{The stakeholder involvement in the place branding of the rural regions}

In the focus group discussions, the issue of 'stakeholder engagement' was seen as central to place branding in the case areas. First of all, identifying the different actors and their responsibilities in place branding seemed to be a demanding task. The field is heterogeneous and the division of tasks is often not clear. It was stated that the coordinative responsibility belongs to public authorities and public operators, that is, to joint regional alliances, federations of municipalities, local organizations or area trade organizations. They are expected to take overall responsibility for coordinating the place branding process. However, when evaluating the current status of place branding, the responsibility for coordination seemed to be unclear, as incoherent co-operational forms existed on various levels with various operators. Municipality-level authorities often concentrate on municipal image construction, and therefore the lack of county- or regional-level thinking was mentioned as a current challenge. This is in line with Hankinson's criticism $(2001,2004)$ of the current situation where individual local authority departments develop separate brands, rather than the local authority developing a unified place brand. 
The active role of the private sector was stressed, and this group was placed the core of place branding. Every encounter with a relevant stakeholder is considered to have an impact on the place brand as a whole. It was also suggested that private operators need to broaden their cooperation with bigger business corporations and governmental institutions, whose activities indirectly affect local development. While external project funding was seen to speed up network cooperation, private entrepreneurs and local associations were also expected to commit to voluntary activities to strengthen area development. The role of the media in strengthening local identity was also highlighted.

In the case regions, place branding has gradually shifted from public-led branding to private-led branding. The private actors were stated to be: (1) leaders in cooperative branding activities, (2) initiators of new activities, (3) content providers for strategic place branding activities, and (4) mirrors reflecting the place image in their local activities. The public actors in turn have: (1) a coordinating role directing future activities in the same direction, (2) a co-creative role - defining the roles and responsibilities together with the private operators, and finally (3) a cooperative role - helping local actors to join with place branding networks. In all of these responsibilities, the quality of public-private partnerships was seen as crucial.

\section{Cooperation among the stakeholders}

It was commonly agreed that the shared vision of a place brand works as an umbrella for diverse activities in the area. Within the rural regions investigated shared vision connected with the landscape was particularly stressed. Place branding should be led by a common vision that offers resources for smaller operational units. The vision helps in constructing stronger profiles for a particular place. It was suggested that this issue needs to be examined from two perspectives. First, the coordinative responsibility of the public sector for communication and the marketing of the place must be clearly stated, so that the private actors are guided in the direction of the cooperative objectives that have been set. Second, under this brand umbrella, private actors can act more independently to focus their action and develop place branding tools in light of their own strengths and qualifications in the area. The main goal, however, remains unchanged: to cooperate according to the common vision and simultaneously be supported by the umbrella. As the private field can be fragmented, policy-making procedures in the place branding process will offer support and guidelines for the smaller operational units.

It was suggested that when network cooperation has gained a strong foothold and legitimacy, the network might be interpreted as the 'owner' of the place brand images, services and products. The network 'owns' these offerings, and hence the outcome is not to be directly associated with the original service provider, but with the network as a whole. In all three case areas, the outcome in local development projects was that the cooperation with the stakeholder groups had succeeded in creating a strong umbrella brand under which communication and cooperation had been implemented. In this way the private operators gain value from belonging to this network. In addition, it was suggested by the private sector, namely, small-scale and unofficial local cooperation by interdependent actors. The latter form of cooperation was seen as often more advantageous and also as contributing to the public good of the whole community.

Contradictory visions between the various actors in the networks were also considered a central issue. Public authorities, private entrepreneurs and clients evaluate a place from different perspectives, in accordance with their particular level of operations and involvement. Internal and external interpretations may differ from each other. Conflicts between various actors and operating levels might also be seen as an indicative of a struggle for power or a reaction to a competitive market. Competition 
was recognized in the business domain, and this was said to slow down the operations of public authorities.

\section{Features of place used in place branding}

In the focus group discussions, the participants saw the natural environment and landscape as core elements of the rural place experience. The place experience was strongly connected with the local people and local identity, as it also was with the service providers. The natural environment and landscape were considered to serve as backdrop for the overall rural place experience.

It was suggested by the participants that we are experiencing a shift from exploiting the land and its assets to acknowledging the intangible value of the landscape. A landscape does not have a price tag on it, but the natural environment and landscape function as frames for the various experiences and provide opportunities for joint place branding in rural regions. Landscape by itself does not have tangible properties that are unchanging. Therefore, public and private stakeholders need to agree upon what meaning they construct for the natural environment and landscape, and what experiences they wish to emphasize and support by their actions. This can be seen as a special feature in rural place branding.

Table 2. Main findings for the three research questions

\begin{tabular}{|c|c|c|}
\hline $\begin{array}{l}\text { Stakeholder } \\
\text { involvement in } \\
\text { place branding of } \\
\text { the rural region }\end{array}$ & $\begin{array}{l}\text { 4) } \\
5)\end{array}$ & $\begin{array}{l}\text { Engaging stakeholders and clarifying their responsibilities in place branding is a critical } \\
\text { task. } \\
\text { The responsibility of place branding coordination belongs both to public authorities } \\
\text { and public operators. } \\
\text { Problems in place branding are unclear and incoherent cooperation forms at various } \\
\text { levels with various operators. } \\
\text { Municipality level authorities may lack county or regional level thinking. } \\
\text { The media have an important role in strengthening the local identity. }\end{array}$ \\
\hline $\begin{array}{l}\text { Cooperation } \\
\text { among the } \\
\text { stakeholders }\end{array}$ & $\begin{array}{l}\text { 1) } \\
\text { 2) }\end{array}$ & $\begin{array}{l}\text { A shared vision of the place brand works as an umbrella. } \\
\text { Small-scale and unofficial local cooperation is advantageous in bringing public good } \\
\text { for the whole community. } \\
\text { Cooperation networks with a strong basis and legitimized form can be the 'owner' of } \\
\text { the place brand images, services and products. } \\
\text { The brand interpretation of the various stakeholders may differ from each other } \\
\text { which call for dialogue and negotiation. } \\
\text { A coordinating body is needed to facilitate the place branding process. }\end{array}$ \\
\hline $\begin{array}{l}\text { Features of rural } \\
\text { regions used in } \\
\text { place branding }\end{array}$ & $\begin{array}{l}\text { 1) } \\
\text { 2) }\end{array}$ & $\begin{array}{l}\text { Natural environment and landscape serve as backdrop for the place experience. } \\
\text { The place experience is connected with the local identity, people and service } \\
\text { providers. } \\
\text { There is a shift from exploiting the land and its assets to acknowledging the intangible } \\
\text { value of the landscape. } \\
\text { The added value of the landscape of the place needs to be clearly identified and } \\
\text { described in a joint process. } \\
\text { Network actors need to agree upon the meaning constructed and support this by } \\
\text { their various actions. }\end{array}$ \\
\hline
\end{tabular}




\section{CONCLUSIONS}

The establishment of a body that will assemble all the relevant stakeholders and coordinate actions is seen as a necessity for any place branding effort. However, in all three rural regions, anxiety was expressed over the coordination and implementation of the operational place branding activities. In instances where the private operators were not satisfied with the work done on the administrative level and, in particular, on the implementation of the place branding process, the brand vision remained vague. As a managerial implication, it is suggested here that it is vital to arrange strategic coordination among the actors involved in place branding, as well as an internal 'brand culture' among them, and also to engage the local population in place branding.

The landscape is an important feature that adds meaning to a rural region. With rural regions landscape is readily available as a medium for branding and may bring local groups and initiatives together. Landscape, along with regionally identified products and services, can create a sense of regional identity and a heightened awareness of the existing natural and cultural qualities of a place. In the rural regions studied here, natural environment and landscape were seen as a foundation for the development of further cooperation by the various actors. The stakeholders need to agree on the meaning constructed for the natural environment and landscape, and the target experiences related to these. This was recognized in the investigated rural areas but was not yet used to its full potential, because place branding also needs a variety of joint projects that strengthen the meaning of the place brand along with good organizing capacity on the part of the stakeholders.

If the cooperative endeavour of the stakeholders is insufficiently effective, then the synergy of the various forms of cooperation will also be limited. In the rural areas investigated here, cooperative endeavour was reported to be adequate from time to time, but in general close cooperation was not seen as an ongoing long-term activity. The identity of the place was often not considered strong enough and, accordingly, the joint place branding activities lacked long-term commitment and consistency.

Places are not products in the traditional sense of the word, and if we wish to apply branding to places, it will need to be a branding framework that applies specifically to places (Kavaratzis and Ashworth, 2008) and, in this case, rural places. The branding strategy of a place needs to be embodied through the aims, communication, values, and the general culture of the place's stakeholders and the overall design for the place (Zenker and Braun, 2010). In branding rural places the meaning of landscape is emphasized. However, without some sense of the people and their particular characteristics and ability, a place is just an empty landscape (Anholt, 2007). Through stakeholder engagement, including variety of local actors, new joint place branding activities can be created that transform and reconstitute the place brand in new ways, rather than simply using brand promotion as an activity to justify the place, its services and its products. Working on joint place branding entails shared responsibilities and views. The recognition and affirmation of the identity of the place is of paramount importance, especially among private actors in rural areas. A strong place identity forms the basis for the co-creation of the place brand and with rural places investigated here the place identity connected with the natural landscape is an important and special element in the co-creation process. Also, according to this study, it supports joint place branding activities and sustains quality in branding. Therefore, there is a need for a regional strategy that aims to confirm both a sense of solidarity and place identity.

Place brands are jointly developed and delivered by public and private sector organizations who build relationships not owned or controlled by a single organization (Hankinson, 2010). If a public organization coordinates the network, it must ensure that its aspirations are in harmony with local needs and expectations (Pike, 2005). When community networks are dependent on local authorities, 
this may reinforce existing social dependencies and conflicting interests (Warner, 2001). Therefore, and as a theoretical implication, place branding activities need to be seen as (co)led by private operators. In the rural regions investigated, place branding has changed over time from a public-led to a private-led activity. Private operators and service providers were seen as the main operative engines in the network, while the umbrella brand preferably needs to be provided by a joint regional alliance, for example a federation of municipalities or an area trade organization. Geographical borders were not seen as central; instead, regional identity was stressed. These findings are in line with Maessen et al. (2007), according to whom regional identity and social networks, rather than official borders, are taken as the frames of reference. Place branding of rural areas is seen as a participative process with the aim to create a strong regional identity that has economic and social benefits.

This study provides a picture of place branding in rural areas in Finland at a particular moment in time. Future longitudinal research on the networks of rural places may yield greater insight into the process of forming a trusting atmosphere and its importance in the sustainable development of place branding. According to this study, place branding in rural areas needs to use the added value of the landscape, but it also relies on stakeholder engagement, a clear division of responsibilities, and strong strategic cooperation between the public and private sector. Place branding efforts need to include local communities at all steps of the branding process (Kavaratzis and Ashworth, 2008), and remember that relationship quality is at the heart of successful place branding. This aspect was also stressed in the rural areas investigated here; however, the level of commitment of local communities differed and was weak in some cases. Because of the importance of coordination among the stakeholders, future research should focus more on factors that enable the cooperation and shared meaning in the place branding process.

\section{Acknowledgements}

The paper is part of a Sitra-funded project 'Strategic management of product-development and branding of the natural environment', focusing on joint place branding of rural regions. The empirical research was conducted during the period April - November 2011.

\section{References}

Aitken, R. and Campelo, A. (2011) The four Rs of place branding. Journal of Marketing Management, 27(9/10): 913-33.

Anholt, S. (2008) Place branding: Is it marketing or isn't it? Place Branding and Public Diplomacy 4(1): 1 6.

Anholt, S. (2007) Competitive Identity. The New Brand Management for Nations, Cities and Regions. Hampshire: Palgrave Macmillan.

Baker, B. (2007) Destination Branding for Small Cities: The Essentials for Successful Place Branding. Portland: Creative Leap Books.

Baker, M. and Cameron, E. (2008) Critical success factors in destination marketing. Journal of Tourism and Hospitality Research 8(2): 79 - 97.

Ballantyne, D. and Aitken, R., (2007) Branding in b2b markets: Insights from the service-dominant logic of marketing. Journal of Business and Industrial Marketing 22(6): 363 - 371.

Barbour, R. (2008) Introducing Qualitative Research. A Student Guide to the Craft of Doing Qualitative Research. London: Sage Publications. 
Berglund, A-K. (1998) Lokala Utvecklingsgrupper på Landsbygden. Uppsala: Uppsala Universitet, Dept. of Social and Economic Geography. Geografiska regionstudier no. 38.

Berleant, A. (1997) Living in the Landscape: Toward an Aesthetics of Environment. Lawrence, KS: University Press of Kansas.

Bloor, M., Frankland, J., Thomas, M. and Robson, K. (2001) Focus Groups in Social Research. London: Sage.

Bryman, A. (2004) Social Research Methods. New York, NY: Oxford University Press.

Cawley, M., Gaffey, S. and Gillmor, D.A. (2002) Localization and global reach in rural tourism: Irish evidence. Tourist Studies 2(1): 63 - 86.

de Chernatony, L. and Dall'Olmo Riley, F. (1998) Defining a 'brand': beyond the literature with experts interpretations. Journal of Marketing Management 14(5): 417 - 443.

Entrikin, J. Nicholas. (1991) The Betweenness of Place: Towards a Geography of Modernity. Baltimore, MD: The John Hopkins University Press.

Flick, U. (1998) An Introduction to Qualitative Research. London: Sage Publication Ltd.

Franklin, A. (2003) Tourism: An Introduction. London: Sage.

Gregory, A. (2007) Involving stakeholders in developing corporate brands: The communication dimension. Journal of Marketing Management 23(1/2): 59 - 73.

Grunig, J. (2006) Furnishing the edifice: ongoing research on public relations as a strategic management function. Journal of Public Relations Research 18(2): 151 - 176.

Hankinson, G. (2010) Place branding research: A cross-disciplinary agenda and the views of practitioners. Place Branding and Public Diplomacy 6(4): 300 - 315.

Hankinson, G. (2004) Relational network brands: Towards a conceptual model of place brands. Journal of Vacation Marketing 10(2): 109 - 121.

Hankinson, G. (2001) Location branding - A study of the branding practices of 12 English cities. Journal of Brand Management 9(2): 127 - 42.

Hatch, M.J. and Schultz, M. (2010) Toward a theory of brand co-creation with implications for brand governance. Journal of Brand Management 17(8): 590 - 604.

Hildreth, J. (2010) Place branding: A view at arm's length. Place Branding and Public Diplomacy 6(1): 27 36.

Hospers, G-J. (2004) Place marketing of Europe: The branding of the Öresund region. Intereconomics 39(5): $271-279$.

Houghton, J.P. and Stevens, A. (2011) City branding and stakeholder engagement. In: K. Dinnie (ed.) City Branding: Theory and Cases. Basingstoke: Palgrave-Macmillan, pp. 45-53.

Jamal, T.B. and Getz, D. (1995) Collaboration theory and community tourism planning. Annals of Tourism Research 22(1): 186 - 204.

Kavaratzis, M. (2004) From city marketing to city branding: Towards a theoretical framework for developing city brands. Place Branding 1(1): 58 - 73.

Kavaratzis, M. (2012) From "necessary evil" to necessity: stakeholders' involvement in place branding. Journal of Place Management and Development 5(1): 7 - 19.

Kavaratzis, M. and Ashworth, G. (2008) Place Marketing: How did we get here and where are we going? Journal of Place Management and Development 1(2): 150 - 165.

Kavaratzis, M. and Hatch, M.J. (2013) The dynamics of place brands: An identity-based approach to place branding theory. Marketing Theory 13(1): 69 - 86.

King, J. (2002) Destination Marketing Organizations: Connecting the experience rather than promoting the place. Journal of Vacation Marketing 8(2): $105-108$. 
Knuuttila, S. (1998) Paikan synty suomalaisena ilmiönä. In: P. Alasuutari and P. Ruuska (eds.) Elävänä Euroopassa. Muuttuva suomalainen identiteetti. Tampere: Vastapaino.

Lichrou, M., O'Malley, L. and Patterson, M. (2010) Narratives of a tourism destination: Local particularities and their implications for place marketing and branding. Place Branding and Public Diplomacy 6(2): 134 - 144.

Lindström, M. (2005) Build Powerful Brands through Touch, Taste, Smell, Sight and Sound. Sensory Secrets behind the Stuff We Buy. New York, NY: Free Press.

Lockie, S., Lawrence, G. and Cheshire, L. (2006) Reconfiguring rural resource governance: The legacy of neo-liberalism in Australia. In: P. Cloke, T. Marsden and P.H. Mooney (eds.) Handbook of Rural Studies. Trowbridge, Wiltshire: The Cromwell Press Ltd.

Low, S.M. and Altman, I. (1992) Place attachment: A conceptual inquiry. In: I. Altman and S.M. Low, S.M. (eds.) Human Behavior and Environment. New York: Plenum Press, pp. 1 - 12.

Lüthje, M. (2005) Se Mukava Maaseutu Siellä Jossain. Maaseutumatkailu Kokemusten, Mielikuvien ja Markkinoinnin Kohteena. Rovaniemi: Lapin yliopisto, Kauppatieteiden ja matkailun tiedekunta. Matkailututkimus, Acta Universitatis Lapponiensis no. 91.

Maessen, R., Wilms, G. and Jones-Walters, L. (2007) Branding our landscapes: some practical experiences from the LIFESCAPE project. Paper presented in Workshop 4, Landscape as a Frame for and a Product of Development in Rural Areas, 8th European IFSA Symposium; 6 - 10 July 2008, Clermont-Ferrand, France.

Merz, M. and Vargo, S. (2009) The evolving brand logic: A service-dominant logic perspective. Journal of the Academy Marketing Science 37(3): 328 - 344.

Morgan, D.L. (1988) Focus Groups as Qualitative Research, Sage, Newbury Park, CA.

Murdoch, J. (2006) Networking rurality: Emergent complexity in the countryside. In: P. Cloke, T. Marsden and P.H. Mooney (eds.) Handbook of Rural Studies. Trowbridge, Wiltshire: The Cromwell Press Ltd.

Murray, C. (2001) Making sense of place: New approaches to place marketing. Pembrokeshire: Comedia Eco-Distribution.

Papadopoulos, N. and Heslop, L. (2002) Country equity and country branding: Problems and prospects. Journal of Brand Management 9(4): 294 - 315.

Pike, S. (2005) Tourism destination branding complexity. Journal of Product and Brand Management 14(4): $258-259$.

Pine, B.J.II and Gilmore, J.H. (1999) The Experience Economy. Boston, MA: Harvard Business Scholl Press. Rainisto, S. (2003) Success factors of place marketing: A study of place marketing practices in Northern Europe and the United States. Institute of Strategy and International Business Doctoral Dissertations 2003/4, Helsinki University of Technology, Monikko Oy, Espoo.

Rannikko, P. (2000) Kehittämishanke paikallisen identiteetin muovaajana. In: T. Hyyryläinen and P. Rannikko (eds.) Eurooppalaistuva Maaseutupolitiikka. Paikalliset Toimintaryhmät Maaseudun Kehittäjinä. Jyväskylä: Gummerus.

Relph, E. (1986) Place and Placelessness. London: Pion.

Silvennoinen, H., Tahvanainen, L. and Tyrväinen, L. (1998) Luonto ja maisema lomakohteen vetovoimatekijöinä: Maatila- ja luontomatkailun erityisvaatimukset. In: J. Saarinen and J. Järviluoma (eds.) Kestävyys Luonnon Virkistys ja Matkailukäytössä. Metsäntutkimuslaitoksen tiedonantoja 671, Metsäntutkimuslaitos, Rovaniemen tutkimusasema, Rovaniemi, pp. 109-127.

Solatie, J. (2001) Focusryhmät. Kvalitatiiviset Ryhmäkeskustelut Strategisen Markkinointitutkimuksen Apuna. Helsinki: Mainostajien liitto, Makeprint. 
Szondi, G. (2010) From image management to relationship building: A public relations approach to nation branding. Place Branding and Public Diplomacy 6(4): 333 - 343.

Tarssanen, S. and Kylänen, M. (2006) A Theoretical Model for Producing Experiences. Rovaniemi: Lapland Centre of Expertise for the Experience Industry.

Tuan, Yi-Fu. (1974) Topophilia: A Study of Environmental Perception, Attitudes and Values. Englewood Cliffs, NJ: Prentice Hall.

Vargo, S.L. and Lusch, R.F. (2004) Evolving to a new dominant logic for marketing. Journal of Marketing 68(1): 1 - 17.

Warner, M. (2001) Building social capital: the role of local government. The Journal of Socio- Economics 30: $187-192$.

Zenker, S. and Braun, E. (2010) The place brand centre - a conceptual approach for the brand culture. London and New York: Routledge. 